University of Nebraska - Lincoln

DigitalCommons@University of Nebraska - Lincoln

\title{
Big Bluestem and Indiangrass from Remnant Prairies: Plant Biomass and Adaptation
}

\author{
Kenneth P. Vogel \\ University of Nebraska-Lincoln, kvogel1@unl.edu \\ K. D. Johnson \\ Purdue University \\ I. T. Carlson \\ lowa State University \\ Marty R. Schmer \\ USDA-ARS, marty.schmer@ars.usda.gov
}

Follow this and additional works at: https://digitalcommons.unl.edu/usdaarsfacpub

Vogel, Kenneth P.; Johnson, K. D.; Carlson, I. T.; and Schmer, Marty R., "Big Bluestem and Indiangrass from Remnant Prairies: Plant Biomass and Adaptation" (2018). Publications from USDA-ARS / UNL Faculty. 1964.

https://digitalcommons.unl.edu/usdaarsfacpub/1964

This Article is brought to you for free and open access by the U.S. Department of Agriculture: Agricultural Research Service, Lincoln, Nebraska at DigitalCommons@University of Nebraska - Lincoln. It has been accepted for inclusion in Publications from USDA-ARS / UNL Faculty by an authorized administrator of DigitalCommons@University of Nebraska - Lincoln. 


\title{
Big Bluestem and Indiangrass from Remnant Prairies: Plant Biomass and Adaptation
}

\author{
Kenneth P. Vogel,^ K. D. Johnson, I. T. Carlson, and Marty R. Schmer
}

\begin{abstract}
Big bluestem (Andropogon gerardii Vitman) and indiangrass (Sorghastrum nutans L.) were collected from remnant Midwestern prairies and evaluated as individual prairie accessions in replicated space-transplanted nurseries near Mead, NE, Ames, IA, and West Lafayette, IN. The objective was to determine the extent of differences among the accessions for plant biomass ( $\mathrm{g}$ plant $^{-1}$ ) and biomass quality, the extent of strain $\times$ location interactions, and the relationship between geographical locations of collection sites and evaluation locations for plant biomass production. Plant biomass has been used previously as a measure of plant adaptation and fitness. Big bluestem and indiangrass accessions differed significantly $(P<$ $0.05)$ for plant biomass at all locations. Strain mean squares for plant biomass were $10 \times$ greater than strain $\times$ location effects for big bluestem and were not significant for indiangrass, indicating a general lack of specific adaptation across the Midwest. Accessions were identified that had high plant biomass at all three locations. These accessions should have value in breeding programs and for use in revegetation. Regression analyses were used to test the effect of north-to-south, east-to-west, and direct distances between the collection sites and the evaluation locations on plant biomass. The most important distance effects were the north-to-south effects, which were significant for plant biomass for big bluestem at all locations and for indiangrass at West Lafayette. Moving northern big bluestem accessions south resulted in reduced plant biomass, with the opposite effect when southern accessions were moved north. Results support the regional adaptation of the best accessions and cultivars for these grasses.
\end{abstract}

K.P. Vogel (retired), USDA-ARS, Grain, Forage, and Bioenergy Research Unit, 251 Filley Hall, Dep. of Agronomy and Horticulture, Univ. of Nebraska, Lincoln, NE 68583-0937; K.D. Johnson, Dep. of Agronomy, Purdue Univ., West Lafayette, IN 47907-2054; I.T. Carlson (retired), 2101 Agronomy Hall, Iowa State Univ., Ames, IA 50011-1010; M.R. Schmer, USDA-ARS, Agroecosystems Research Unit, 251 Filley Hall, Dep. of Agronomy and Horticulture, University of Nebraska, Lincoln, NE 68583-0937. Mention of a trade name does not constitute a guarantee of the product by USDA or the University of Nebraska and does not imply its approval to the exclusion of other suitable products. Received 22 Sept. 2017. Accepted 5 Dec. 2017. *Corresponding author (vogelkp61@neb.rr.com). Assigned to Associate Editor Michael Casler.

Abbreviations: IVDMD, in vitro dry matter digestibility.

Drior to the $1800 \mathrm{~s}$, the tallgrass prairie region of North 1 America occupied $>500,000 \mathrm{~km}^{2}$ of central North America in what is now the Midwestern states or Corn Belt region of the United States (Risser et al., 1981). Because of the development of agriculture in this region, only remnants of the original prairie remain in most of the region, but the grasses from this prairie ecoregion are now being used in agricultural production systems (e.g., conservation, forage, and bioenergy). There is currently considerable research effort on developing switchgrass (Panicum virgatum L.) into a biomass energy crop (McLaughlin and Kszos, 2005; Vogel et al., 2011). In addition to switchgrass, other native North American prairie grasses including big bluestem (Andropogon gerardii Vitman) and indiangrass (Sorghastum nutans Nash) are also being evaluated and developed for use as bioenergy grasses in multispecies plantings. These grasses have been used previously in warm-season pastures and for conservation and wildlife plantings in the Great Plains and Midwest of the United States (Moser and Vogel, 1995; Boe et al., 2004; Mitchell and Vogel, 2004). Cultivars of big bluestem and indiangrass have been developed by breeding programs located primarily in Nebraska, South Dakota,

Published in Crop Sci. 58:728-738 (2018).

doi: $10.2135 /$ cropsci2017.09.0572

(C) Crop Science Society of America | 5585 Guilford Rd., Madison, WI 53711 USA All rights reserved. 
Kansas, and Oklahoma and by Plant Materials Centers of the USDA-Natural Resources Conservation Service (NRCS) (Alderson and Sharp, 1994; Vogel, 2000; Boe et al., 2004; Mitchell and Vogel, 2004). Although cultivars from these programs have been effectively used in the Midwestern states, it was recognized that the germplasm base for these grasses needed to be expanded with additional germplasm collected from remnant prairies in the US Midwest.

In autumn 1989, seeds of switchgrass, big bluestem, indiangrass, and Canada wildrye (Elymus canadensis L.) were collected from remnant prairies in this region. The collected seed was used to produce seedlings that were used to establish multilocation evaluation trials in field nurseries. Insufficient seed was collected for submission to germplasm depositories. The results of the switchgrass evaluation trials (Hopkins et al., 1995) and Canada wildrye trials (Vogel et al., 2006a) have been reported previously. In this report, the variation among big bluestem and indiangrass accessions for biomass yield and in vitro dry matter digestibility $(I V D M D)$ and the extent of strain $\times$ location interaction effects are summarized. In addition, the data from the evaluation trials were used to determine the relationship between the geographical location of the collection site and evaluation location for these accessions for plant adaptation fitness as measured by biomass production. This relationship was examined because of the emphasis that many ecologists and some government agencies are placing on the use of "local" ecotypes in restoration and conservation plantings. Plant biomass production or plant size has been used in ecological studies as a measure of plant adaptation to a location (Byers, 1998; Montalvo and Ellstrand, 2001; Gustafson et al., 2004).

The tallgrass prairie region of North America is classified as the Prairie Parkland (Temperate) ecoregion province in the widely used ecoregion classification system developed by Bailey (1995). Vogel et al. (2005) overlaid Bailey's ecoregion province classification system map with the USDA Plant Hardiness Zone Map (Cathey, 1990) to develop Plant Adaptation Regions, which integrate the ecological and climatic variables that affect plant adaptation in a region. Evaluation locations and the prairies or sites of the germplasm collections are shown on Plant Adaptation Region maps for big bluestem (Fig. 1) and indiangrass (Fig. 2). The three evaluation locations represent the east-to-west range of this prairie ecoregion and were in the northern part of USDA Plant Hardiness Zone 5 during the time period in which the evaluations were conducted.

\section{MATERIALS AND METHODS}

In this report, "site" refers to the prairie area from which the seed of an accession was collected, and "location" refers to the three field areas where the evaluation trials were conducted Accessions were designated by the postal code of the state in which the prairie was located, followed by a sequential number assigned to a specific prairie within the state. In addition to the prairie accessions, cultivars and experimental breeding populations of both big bluestem and indiangrass were included in the trials as check or control entries. Prairie accessions, cultivars, and experimental strains are all referred to as "strains" for simplification purposes in procedures, results, and discussion where applicable.

Big bluestem and indiangrass collections were made in autumn 1989 from remnant prairie sites. Most of the collection sites were being preserved by local, state, or federal governments or private organizations All accessions originated from unplanted, native prairie sites except for IL62, which was from a restored prairie planted in 1940. Permission to collect seed was obtained from the owners or custodians of the prairies. Collection sites are representative of the remnant prairie sites that exist in the region. Seeds were hand stripped from plants by species from each remnant site in a random manner. Seed from a site was dried on a greenhouse bench in paper bags and then threshed.

Cleaned seed from each accession was stratified for $3 \mathrm{wk}$ at $4.5^{\circ} \mathrm{C}$ and planted in the greenhouse in February 1990 into plastic seedling tubes (22 cm deep and $4 \mathrm{~cm}$ in diameter), which contained a mixture of 2:1:1 soil/peat/vermiculite. After emergence, seedlings were thinned to one seedling per tube. Seedlings of the accessions and the check strains were transplanted into separate nurseries or gardens by species at each location into single-row plots. The field evaluation locations were near Mead, NE, Ames, IA, and West Lafayette, IN. The nurseries were transplanted in late May or early June in 1990. Soil type was Sharpsburg silt loam (silty clay Typic Argiudoll) at Mead, Webster silty clay loam (fine-loamy, mixed, mesic Typic Haplaquoll) at Ames, and Xenia silt loam (Typic Haplaquoll) at West Lafayette. Climatic conditions at the three sites for the duration of the trial are summarized in Table 1. The experimental design was a randomized complete block with two replicates or blocks at Ames and West Lafayette and three at the Mead location. A plot consisted of a single row of 10 plants with rows and plants within a row spaced $1.1 \mathrm{~m}$ apart. Sixty germplasm accessions of big bluestem and 20 accessions of indiangrass were evaluated at the three sites. Big bluestem and indiangrass accessions evaluated at the three locations were those for which sufficient seedlings were produced from the collected seed to be included in the study. There was a single row of border plants of the same species on the sides of the nursery. Blocks of plots within the nurseries were separated by a $1.1-\mathrm{m}$ unvegetated gap.

During the establishment and postestablishment year, herbicides and hand weeding were used for weed control. The herbicides, rates, and application dates varied with location and year but typically included herbicides for preemergence control of both grassy and broadleaf weeds that were applied in the spring each year. The nurseries were fertilized with $112 \mathrm{~kg} \mathrm{~N} \mathrm{ha}^{-1}$ as ammonium nitrate in April or early May of 1991 and 1992 at each location. No fertilizers were applied the establishment year. No data were collected in the 1990 establishment year. The plots were evaluated for stands, plant biomass production, and forage-quality traits in 1991 and 1992. Stand data were obtained by counting the number of surviving plants in a row. Plots were harvested for biomass yield after plants were headed (maturity stage R3; Moore et al., 1991). There were multiple harvests dates each year 


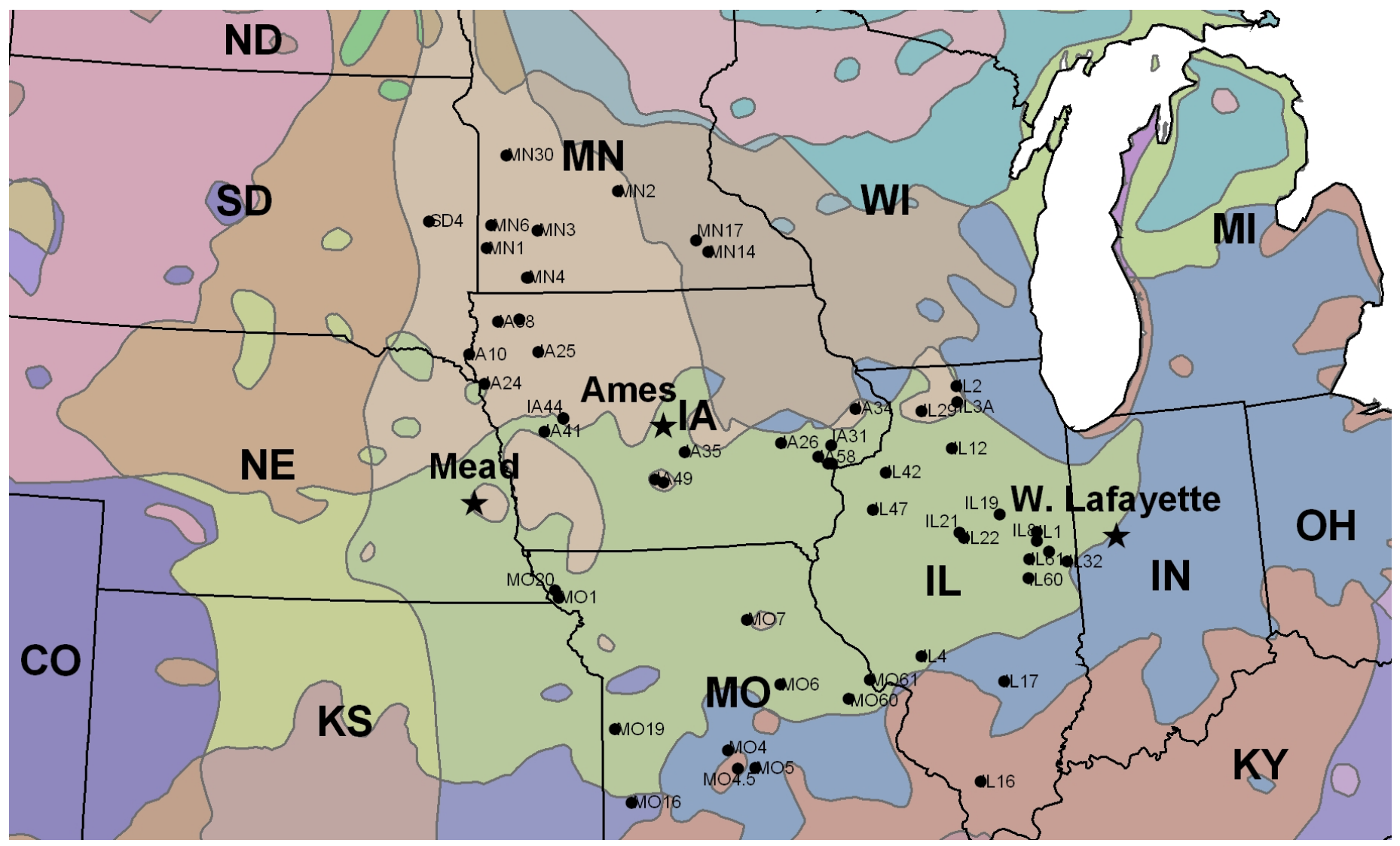

Fig. 1. Big bluestem prairie collection sites (dots), evaluation locations (stars), and Plant Adaptation Regions (colored regions). Plant Adaptation Regions (PAR) are: PAR 251-5 (light green; temperate prairie parkland, Plant Hardiness Zone 5), PAR 251-4 (tan), PAR 222-4 (light brown; eastern broadleaf forest, Plant Hardiness Zone 4), and PAR 222-5 (blue).

at each location because of differences in maturity of the accessions. Heading dates ranged from mid-July to mid-September for both species. Accessions were harvested as they matured on approximately a weekly basis. Biomass samples were collected at the time of harvest for forage quality analyses by cutting three to four tillers, at $\sim 10 \mathrm{~cm}$ of height, from each plant within a plot.

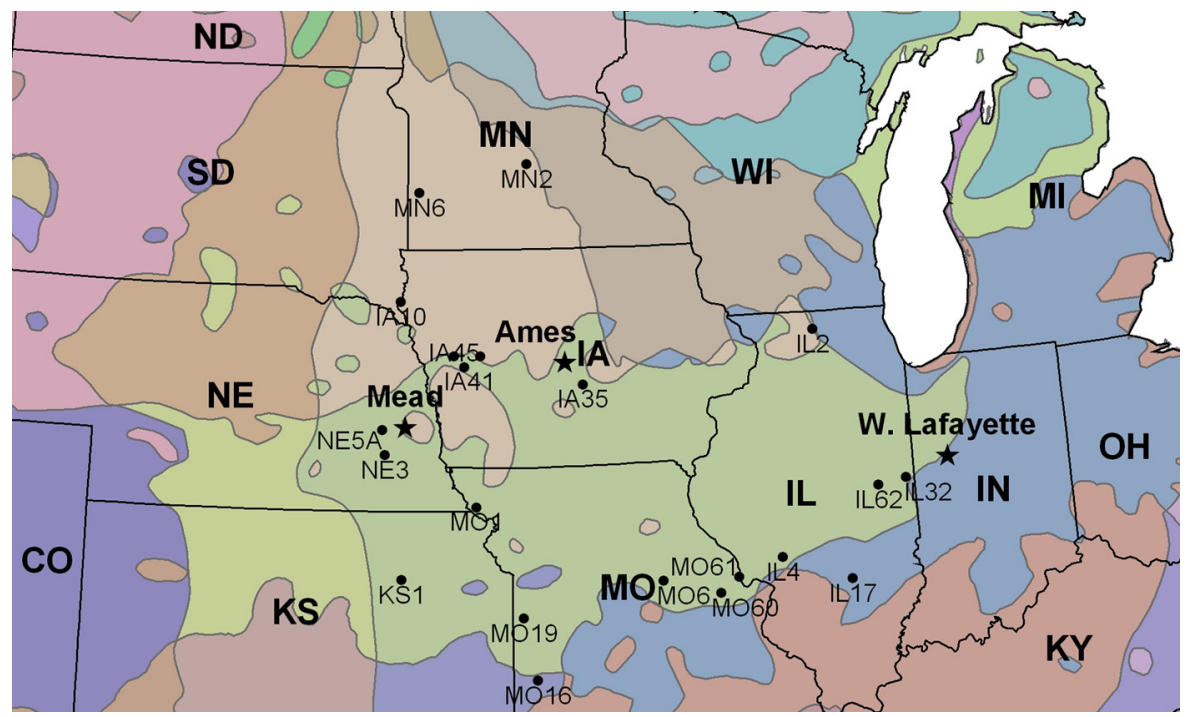

Fig. 2. Indiangrass prairie collection sites (dots), evaluation locations (stars), and Plant Adaptation Regions (colored regions). Plant Adaptation Regions (PAR) are: PAR 251-5 (light green; temperate prairie parkland, Plant Hardiness Zone 5), PAR 251-4 (tan), PAR 222-4 (light brown; eastern broadleaf forest, Plant Hardiness Zone 4), and PAR 222-5 (blue).
Samples were dried in forced-draft ovens at $50^{\circ} \mathrm{C}\left(60^{\circ} \mathrm{C}\right.$ at West Lafayette) to determine dry matter concentrations of the samples, which were used to adjust forage biomass yields to a dry-weight basis. Plots were harvested at a height of $10 \mathrm{~cm}$ using a flail plot harvester. Dry weight of the forage samples collected from each plot for dry matter and quality analysis was added to the plot forage yield. The number of plants in each plot at harvest was determined and plant biomass was expressed as dry weight per plant $\left(\mathrm{g}\right.$ plant $\left.^{-1}\right)$ by dividing plot yield by the number of harvested plants per plot. This was necessary because some seedlings died after transplanting. There was minimal stand loss after the establishment year, so stands are not reported.

Dried forage samples were ground in a Wiley shear mill to pass a $1-\mathrm{mm}$ screen and reground to uniformity in a cyclone impact mill. All samples were scanned using a nearinfrared reflectance spectrophotometer (Technicon Infralyzer 500, Bran \& Luebbe Analyzing Technologies) over a wavelength range of 1100 to $2500 \mathrm{~nm}$ with 2-nm steps. Although detergent fiber and crude protein were determined, only IVDMD data are reported in this paper. Development and verification of prediction equations for IVDMD on wet laboratory values were as described by Hopkins et al. (1995). The prediction 
equations for IVDMD had a $R^{2}$ value of 0.96 and a standard error of calibration of $25 \mathrm{~g} \mathrm{~kg}^{-1}$.

An ANOVA across locations was conducted to determine if there were significant differences among strains for biomass yield and IVDMD and to determine the relative magnitude of strain $\times$ location interaction effects. Because big bluestem and indiangrass are perennials, the across locations analyses were conducted using 2-yr plot means, and strains and locations were fixed effects. Single location analyses were conducted to determine if there were significant differences among strains at each evaluation location using years as a split-plot in time. In these analyses, strains were considered to be fixed effects. PROC GLM of SAS (SAS Institute, 1999) was used in the ANOVA for both across location and single location analyses. The method of Neter et al. (1985) was used to calculate approximate F-values, and approximate degrees of freedom were calculated according to Satterthwaite (1946) in the analyses used for single locations in which years were random effects.

Linear regression analysis was conducted to determine if the distance of the collection site from the evaluation location had an effect on individual plant biomass yield. A Cartesian grid was placed over a map (Fig. 3) on each of the three evaluation location and the distance north $(+)$, south $(-)$, east $(+)$, or west $(-)$ of the collection site from the evaluation site was determined. Regression analysis was done for the effect of direct distance, north or south distance, and east or west distance on individual plant biomass $\left(\mathrm{g}\right.$ plant $^{-1}$ ) using PROC REG (SAS Institute, 1999). The regression prediction equation for predicting the effect of direction and distance of the prairie from which an accession was collected on its plant biomass production at one of the evaluation locations is listed below:

$$
\hat{Y}=\bar{Y}+b(X)
$$

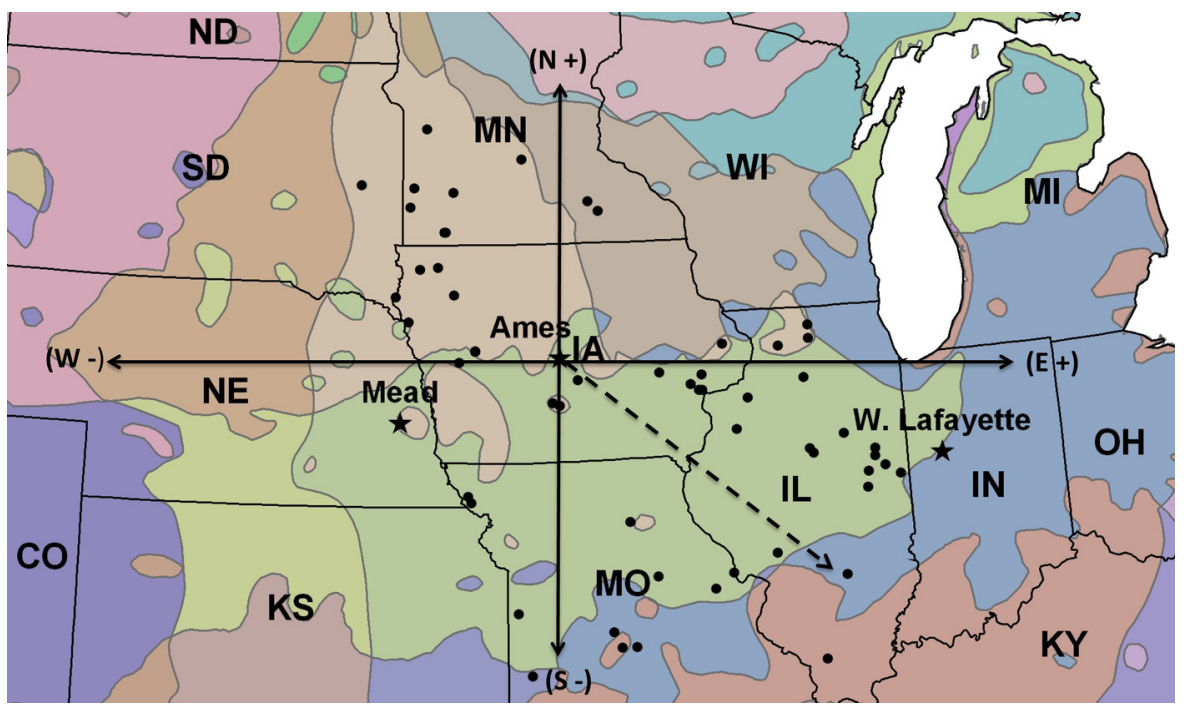

Fig. 3. Illustration of the axis lines of Cartesian grid that was overlaid at the Ames, IA, location to measure the north (+), south (-), east (+), and west (-) directional distance of each collection site from the Ames evaluation location. The direct-distance measurement is illustrated with the dashed arrow line. The same process was repeated at the Mead and West Lafayette evaluation locations. The direct and direction distance of the evaluated accessions of a species were used in regression analyses to determine the effect of direct distance, direction distance, north or south distance, and east to west distance on plant biomass for each of the three evaluation locations for big bluestem and indiangrass. where $\hat{Y}$ is the predicted plant biomass $\left(\mathrm{g}\right.$ plant $^{-1}$ ) of an accession at an evaluation location, $\bar{Y}$ is the mean plant biomass at the evaluation location, $b$ is the regression coefficient $\left(\mathrm{g} \mathrm{km}^{-1}\right)$, and $X$ is the distance (direct or directional) in kilometers of the collection prairie site from the evaluation location. Based on the Cartesian grid, directional distances had positive (north or east) or negative values (west or south), whereas all direct distances were given positive values. Coefficients of determination $\left(R^{2}\right)$ values and regression coefficients are reported for the regressions for both species. The $R^{2}$ values represent the proportion of the total variation of the dependent variable (biomass yield) that is attributable to the independent variable (distance). Regression analysis was conducted on 56 big bluestem and 19 indiangrass accessions for which complete yield and distance values were available. Cultivars, experimental strains, and the accession from a planted prairie were excluded from the regression analyses.

\section{RESULTS \\ Strain Means and Strain $\times$ Location Interaction Effects}

The environmental conditions during the evaluation period at the three locations were representative of the environmental variation that exists in the temperate prairie parkland or tallgrass prairie ecoregion of the United States over years (Table 1). Annual precipitation was substantially below the long-term average at West Lafayette in 1991. Precipitation was below the average for all three locations in 1992. Temperatures were somewhat warmer and cooler than normal, respectively, in 1991 and 1992 at the three locations.

There was minimal loss of transplanted plants during the establishment year (data not shown). To compensate for missing plants in some plots, plant biomass is reported as grams per plant. There were significant differences among the big bluestem and indiangrass strains evaluated at the three locations over the 2 -yr evaluation period for plant biomass (Table 2). There were significant strain $\times$ location interaction effects for the big bluestem, but the mean squares for the strain effects were almost 10-fold greater than mean squares for the strain $\times$ location interaction effects, indicating that the big bluestem strains had relatively similar plant biomass across locations. Strain $\times$ location interaction effects for biomass yield were not significant at $P$ $\leq 0.05$ for the evaluated indiangrass strains (Table 2), indicating relative stability for plant biomass across the region. There were significant differences among the big bluestem strains for IVDMD. Strain $\times$ location interaction effects were not significant for this important forage quality trait, 
Table 1. Seasonal climatic data with deviations from the 30-yr average for the 1991 and 1992 growing seasons at Mead, NE, Ames, IA, and West Lafayette, IN.

\begin{tabular}{|c|c|c|c|c|}
\hline \multirow[b]{2}{*}{ Year/location } & \multicolumn{2}{|c|}{ Seasonal precipitation† } & \multicolumn{2}{|c|}{ Monthly temperature† } \\
\hline & Total & Deviation & Average & Deviation \\
\hline & + & $n-$ & $\longrightarrow$ & $\longrightarrow$ \\
\hline \multicolumn{5}{|l|}{1991} \\
\hline Meadf & 528 & 4 & 20.5 & 0.6 \\
\hline Ames & 609 & 95 & 19.6 & 1.1 \\
\hline West Lafayette & 323 & -190 & 20.4 & 1.9 \\
\hline \multicolumn{5}{|l|}{1992} \\
\hline Mead & 379 & -145 & 17.5 & -2.4 \\
\hline Ames & 456 & -58 & 16.9 & -1.5 \\
\hline West Lafayette & 463 & -50 & 16.9 & -1.5 \\
\hline
\end{tabular}

† Growing seasons were April-October 1991 and April-September 1992.

‡ Nearest reporting stations with complete precipitation (Wahoo, NE) and temperature (Ashland, NE) data were used.

indicating that this trait was relatively stable over environments. It has been previously demonstrated in switchgrass that IVDMD is an excellent predictor of ethanol yield from biomass in a biorefinery (Vogel et al., 2017). Indiangrass strains were significantly different for IVDMD at only $P \leq$ 0.10 , and strain $\times$ location interaction effects for indiangrass IVDMD were not significant. There were significant differences $(P \leq 0.05)$ among strains at each evaluation location for plant biomass for both species. In the individual location analyses, strain mean squares for both species were threefold or more greater than the strain $\times$ year mean squares (data not shown), indicating that year effects were of minor importance in comparison with strain effects.

Big bluestem accessions that had the greatest plant biomass averaged over locations also typically had the greatest plant biomass at each of the three locations, although there were some changes in their ranks among locations (Table 3). The West Lafayette site had smaller big bluestem plant biomass than the other locations, probably due to reduced precipitation in 1991 and also in 1992. The 10 accessions with the greatest plant biomass averaged over locations also had plant biomass that was significantly greater than the mean accession yield at each location, with the exception of IA57 at West Lafayette (Table 3). The big bluestem accessions with the lowest plant biomass production also consistently had the lowest biomass production at each of the three locations, and the mean plant biomass of these accessions was lower than the mean plant biomass of all accessions at each location. A few of the accessions with the greatest plant biomass such as IL60 and MO60 had plant biomass equivalent to that of the cultivar 'Kaw', and many of the top 10 accessions had plant biomass production equivalent to the cultivar 'Pawnee' at each location. However, these cultivars had greater IVDMD than any of the high biomass-producing accessions. The IVDMD values averaged over locations are reported because strain $\times$ location interaction effects for IVDMD were not significant. Two experimental breeding populations included in the study, Kaw C2 and Pawnee C2, were developed by two breeding generations or cycles (C) for improved biomass yield and IVDMD using Kaw and Pawnee as the base populations. These two experimental strains had greater plant biomass than their parent populations at all locations, except for Kaw $\mathrm{C} 2$ at Ames, although the differences were not always significant at $P \leq 0.05$. The experimental strains also had numerically greater IVDMD than their parent cultivars and had significantly greater IVDMD than any of the highest biomass-producing accessions.

Results for the indiangrass accessions evaluations were similar to those for the big bluestem accessions. Indiangrass accessions that had the greatest plant biomass averaged over locations also typically had the greatest plant biomass at each of the three evaluation locations (Table 4). Likewise, the accessions that had the smallest plant biomass averaged over locations also tended to have the smallest plant biomass at each location. Some accessions had changes in rank, such as MO6, MO16, MO19, and NE3, which had lower plant biomass than the location mean at West Lafayette but not at Mead or Ames. Indiangrass accessions NE5A and KS1, which had the greatest plant biomass averaged over locations, had plant biomass equivalent to that of the cultivar 'Oto' at Mead and Ames but had numerically lower plant biomass than Oto at West Lafayette. Two experimental strains, Nebraska 54 C2 and Oto $\mathrm{C} 2$, which also were developed by two breeding generations for improved biomass yield and IVDMD, had numerically greater plant biomass than their parent cultivars at each location except for Nebraska 54 C2 at

Table 2. Mean squares summary from the ANOVA for plant biomass production and digestibility (in vitro dry matter digestibility, IVDMD) evaluation of big bluestem and indiangrass germplasm accessions from Midwestern US remnant prairies and adapted cultivars evaluated at Mead, NE, Ames, IA, and West Lafayette, IN, using 2-yr means for 1991 and 1992.

\begin{tabular}{|c|c|c|c|}
\hline \multirow[b]{2}{*}{ Species } & \multirow[b]{2}{*}{ Trait } & \multicolumn{2}{|c|}{ Mean squares (strains $=$ accessions + cultivars) } \\
\hline & & Strains & Strain $\times$ location \\
\hline \multirow[t]{2}{*}{ Big bluestem } & Biomass yield $\left(\mathrm{g} \mathrm{plant}^{-1}\right)$ & $175,171^{\star \star}$ & $18,146^{\star}$ \\
\hline & IVDMD $\left(\mathrm{g} \mathrm{kg}^{-1}\right)$ & $2,949^{* \star}$ & 722 \\
\hline \multirow[t]{2}{*}{ Indiangrass } & Biomass yield (g plant ${ }^{-1}$ ) & $299,661^{*}$ & $66,185 \dagger$ \\
\hline & IVDMD $\left(\mathrm{g} \mathrm{kg}^{-1}\right)$ & $2,236 \dagger$ & 1,351 \\
\hline
\end{tabular}

*, ** Significant at the 0.05 and 0.01 probability levels, respectively.

† Statistically significant at the $P \leq 0.10$ level of probability. 
Table 3. Plant biomass production and digestibility (in vitro dry matter digestibility, IVDMD) means and mean ranges for big bluestem accessions collected from remnant prairies of the US Midwest and cultivars or experimental strains that were evaluated in space-transplanted nurseries located near Mead, NE, Ames, IA, and West Lafayette, IN, during the years 1990 to 1992. Harvests were made after inflorescences had emerged. Accessions listed are those with the 10 highest and 5 lowest plant biomass values averaged over locations.

\begin{tabular}{|c|c|c|c|c|c|}
\hline \multirow[b]{2}{*}{ Accessions } & \multicolumn{4}{|c|}{ Plant biomass } & \multirow{2}{*}{$\frac{\text { IVDMD }}{\text { 3-location mean }}$} \\
\hline & 3-location mean & Mead & Ames & West Lafayette & \\
\hline & & 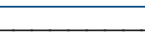 & 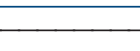 & 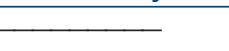 & $\mathrm{g} \mathrm{kg}^{-1}$ \\
\hline \multicolumn{6}{|l|}{ High yields } \\
\hline IL60 & 845 & 1028 & 992 & 565 & 422 \\
\hline MO60 & 782 & 915 & 932 & 458 & 396 \\
\hline MO1 & 771 & 887 & 875 & 485 & 409 \\
\hline IL8 & 744 & 940 & 948 & 338 & 427 \\
\hline MO6 & 739 & 1065 & 810 & 418 & 428 \\
\hline IL32 & 738 & 1062 & 822 & 380 & 430 \\
\hline |A57 & 735 & 862 & 1030 & 230 & 402 \\
\hline IL22 & 729 & 1000 & 778 & 438 & 419 \\
\hline MO20 & 709 & 993 & 800 & 340 & 401 \\
\hline IA55 & 712 & 928 & 830 & 425 & 432 \\
\hline \multicolumn{6}{|l|}{ Low yields } \\
\hline IA37A & 294 & 458 & 322 & 110 & 464 \\
\hline SD4 & 284 & 380 & 380 & 87 & 441 \\
\hline MN6 & 280 & 342 & 328 & 120 & 460 \\
\hline MN4 & 252 & 363 & 308 & 102 & 458 \\
\hline MN1 & 177 & 313 & 168 & 83 & 456 \\
\hline \multicolumn{6}{|l|}{ All accessions } \\
\hline Mean & 547 & 706 & 649 & 287 & 432 \\
\hline Range & $177-845$ & 313-1062 & $168-1030$ & $72-587$ & $396-474$ \\
\hline $\mathrm{N}$ & 60 & 60 & 60 & 60 & 60 \\
\hline \multicolumn{6}{|l|}{ Cultivars } \\
\hline Kaw & 842 & 1043 & 928 & 590 & 451 \\
\hline Kaw C2† & 906 & 1195 & 910 & 655 & 474 \\
\hline Pawnee & 643 & 785 & 770 & 398 & 460 \\
\hline Pawnee C2† & 814 & 1015 & 908 & 490 & 470 \\
\hline $\operatorname{LSD}_{0.05}$ & 154 & 209 & 229 & 124 & 30 \\
\hline
\end{tabular}

† Strain developed by two generations of breeding for increased yield and IVDMD.

Ames. The experimental strains also had numerically greater IVDMD averaged over locations than their parent cultivars. In contrast with the big bluestem accessions, several of the highest yielding indiangrass accessions had IVDMD means equivalent to those of the cultivars and experimental strains.

\section{Regression Analyses: Effect of Direction and Distance on Plant Biomass}

Regression analyses evaluated the effect of distance between each accession's collection site and evaluation location on its plant biomass $\left(\mathrm{g} \mathrm{plant}^{-1}\right)$ at that evaluation location. North-to-south distance effects were highly significant at all three evaluation locations for the big bluestem accessions (Table 5). The $R^{2}$ values for the big bluestem north-to-south regression ranged from 0.29 at Ames to 0.60 at West Lafayette, indicating that differences in latitude between the collection site and evaluation location for big bluestem had a sizable effect on plant biomass of big bluestem accessions. North-to-south regression coefficients (b) for big bluestem ranged from $-0.82 \mathrm{~g} \mathrm{~km}^{-1}$ at Ames to $-0.49 \mathrm{~g} \mathrm{~km}^{-1}$ at West Lafayette. An accession from a site $300 \mathrm{~km}$ north of Ames would be expected to have biomass production per plant at Ames that would be $262 \mathrm{~g}$ smaller than the mean biomass production per plant for all accessions at Ames (insert $300 \mathrm{~km}$ for $X$ and $-0.82 \mathrm{~g} \mathrm{~km}^{-1}$ for $b$ in Eq. [1]), whereas an accession collected $300 \mathrm{~km}$ south of Ames would be expected to have a plant biomass $262 \mathrm{~g}$ greater than the Ames mean (insert $-300 \mathrm{~km}$ for $X$ and $-0.82 \mathrm{~g} \mathrm{~km}^{-1}$ for $b$ in Eq. [1]). These decreases and increases in plant biomass would be significant using the $\mathrm{LSD}_{0.05}$ value for big bluestem strain differences at Ames (Table 3). At Mead, a north or south distance of $350 \mathrm{~km}$ would be expected to have a significant negative or positive effect on plant biomass, whereas at West Lafayette, this distance would be $\sim 250 \mathrm{~km}$.

For indiangrass, there were significant north-tosouth effects for plant biomass only for the West Lafayette location $\left(R^{2}=0.52 ; b=-0.44\right)$ (Table 6). At West Lafayette, 
Table 4. Biomass production per plant and digestibility (in vitro dry matter digestibility, IVDMD) means and mean ranges for indiangrass accessions collected from remnant prairies of the US Midwest and cultivars or experimental strains that were evaluated in space-transplanted nurseries located near Mead, NE, Ames, IA, and West Lafayette, IN, during the years 1990 to 1992. Harvests were made after inflorescences had emerged. Accessions listed are those with the 10 highest and 5 lowest plant biomass values averaged over locations.

\begin{tabular}{|c|c|c|c|c|c|}
\hline \multirow[b]{2}{*}{ Accessions } & \multicolumn{4}{|c|}{ Plant biomass } & \multirow{2}{*}{$\frac{\text { IVDMD }}{\text { 3-location mear }}$} \\
\hline & 3-location mean & Mead & Ames & West Lafayette & \\
\hline & 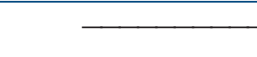 & 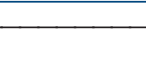 & & 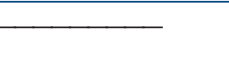 & $\mathrm{g} \mathrm{kg}^{-1}$ \\
\hline \multicolumn{6}{|l|}{ High yields } \\
\hline NE5A & 1074 & 1226 & 1426 & 571 & 462 \\
\hline $\mathrm{KS} 1$ & 1025 & 1336 & 1184 & 556 & 466 \\
\hline MO1 & 787 & 992 & 827 & 581 & 459 \\
\hline NE3 & 765 & 1102 & 798 & 395 & 429 \\
\hline M016 & 745 & 859 & 877 & 368 & 493 \\
\hline IL17 & 728 & 852 & 772 & 560 & 460 \\
\hline M019 & 702 & 1103 & 615 & 389 & 479 \\
\hline IL62 & 666 & 665 & 884 & 448 & 469 \\
\hline IL4 & 664 & 861 & 567 & 566 & 487 \\
\hline MO6 & 656 & 924 & 691 & 352 & 478 \\
\hline \multicolumn{6}{|l|}{ Low yields } \\
\hline IL32 & 577 & 723 & 586 & 423 & 434 \\
\hline M061 & 502 & 557 & 448 & 497 & 489 \\
\hline IL2 & 475 & 528 & 617 & 281 & 439 \\
\hline MN6 & 425 & 808 & 291 & 177 & 462 \\
\hline MN2 & 357 & 572 & 306 & 193 & 486 \\
\hline \multicolumn{6}{|l|}{ All accessions } \\
\hline Mean & 663 & 860 & 705 & 426 & 394 \\
\hline Range & $357-1074$ & 528-1336 & 291-1426 & $177-581$ & $429-498$ \\
\hline $\mathrm{N}$ & 20 & 20 & 20 & 20 & 20 \\
\hline \multicolumn{6}{|l|}{ Cultivars } \\
\hline Nebraska 54 & 893 & 1216 & 1078 & 384 & 441 \\
\hline Nebraska 54 C2† & 1045 & 1512 & 978 & 646 & 453 \\
\hline Oto & 1014 & 1287 & 1035 & 721 & 469 \\
\hline Oto $\mathrm{C} 2 \dagger$ & 1276 & 1901 & 1105 & 824 & 473 \\
\hline Rumsey & 744 & 749 & 653 & 834 & 477 \\
\hline $\operatorname{LSD}_{0.05}$ & 215 & 653 & 513 & 318 & 31 \\
\hline
\end{tabular}

† Strain developed by two generations of breeding for increased yield and IVDMD.

Table 5. Regression statistics for the regression of mean plant biomass (g plant ${ }^{-1}$ ) of big bluestem germplasm accessions from remnant prairies at three Midwestern evaluation sites on the distance $(\mathrm{km})$ and directional distance between the evaluation site and the remnant prairie locations. The coefficients of determination $\left(R^{2}\right)$ quantify the amount of variation in plant biomass production due to the distance and direction effect of the collection site from the evaluation site; the regression coefficients (b) quantify the expected rate of change in plant biomass production with increasing distance of the collection site from the evaluation site. The positive or negative amount of change is dependent on the directional distance of the collection site from the evaluation site. North-south and east-west distance is the distance $(\mathrm{km})$ north $(+)$, south $(-)$, east (+), or west $(-)$ of the collection site from the evaluation site; the direct vector is the positive (+) distance between evaluation and collection site.

\begin{tabular}{|c|c|c|c|c|}
\hline Distance type & Statistic & Mead, NE† & Ames, IA & West Lafayette, IN \\
\hline \multirow[t]{2}{*}{ North-south } & $R^{2}$ & $0.40^{* *}$ & $0.29^{* \star}$ & $0.60^{\star *}$ \\
\hline & $b\left(\mathrm{~g} \mathrm{~km}^{-1}\right)$ & $-0.63^{* *}$ & $-0.82^{\star *}$ & $-0.49^{* *}$ \\
\hline \multirow[t]{2}{*}{ East-west } & $R^{2}$ & $0.38^{\star *}$ & $0.16^{\star \star}$ & $0.21^{* \star}$ \\
\hline & $b\left(\mathrm{~g} \mathrm{~km}^{-1}\right)$ & $0.54^{\star \star}$ & $0.35^{\star \star}$ & $0.26^{\star \star}$ \\
\hline \multirow[t]{2}{*}{ Direct vector } & $R^{2}$ & $0.19^{\star \star}$ & 0.02 & $0.22^{* *}$ \\
\hline & $b\left(\mathrm{~g} \mathrm{~km}^{-1}\right)$ & $0.49^{\star *}$ & 0.08 & $-0.25^{\star \star}$ \\
\hline
\end{tabular}

** Significant at the 0.01 probability level.

$\dagger n=56$ for each location. 
the indiangrass north-to-south distance effects on plant biomass were the same as for the big bluestem accessions. The further south an accession was collected from the evaluation location, the greater the plant biomass with the opposite effect for northern accessions.

All of the evaluated big bluestem and indiangrass accessions were collected west of the West Lafayette evaluation location, whereas most of the accessions were collected east of the Mead location (Fig. 1 and 2). Regression of east-towest distance on plant biomass was significant at all three evaluation locations for big bluestem. The big bluestem $R^{2}$ values ranged from 0.16 at Ames to 0.38 at Mead, indicating relatively lower predictability than the north-to-south regressions. The east-to-west regression coefficients for big bluestem were all positive. East-to-west regression coefficients ranged from $0.26 \mathrm{~g} \mathrm{~km}^{-1}$ at West Lafayette to 0.54 $\mathrm{g} \mathrm{km}^{-1}$ at Mead. Big bluestem accessions collected west of the evaluation locations would be expected to have reduced plant biomass in comparison with those collected east of the evaluation locations. An accession collected $400 \mathrm{~km}$ east of Mead could be expected to exceed the Mead mean plant biomass $\left(\mathrm{g} \mathrm{plant}^{-1}\right)$ by $216 \mathrm{~g}$.

East-to-west distance effects on plant biomass for indiangrass were significant only at Mead $\left(R^{2}=0.26\right.$, $b$ value was negative). This indicates that indiangrass accession collected east of the Mead location would be expected in general to have lower plant biomass but with low predictability. Based on the evaluated accessions, indiangrass accessions from the most eastern part of the tall grass prairie would be expected to have reduced plant biomass at Mead.

Direct-distance effects included both north-to-south and east-to-west components. For both the big bluestem and indiangrass accessions, there was not a significant direct distance effect as shown by the nonsignificance of the coefficient of determination $\left(R^{2}\right)$ and regression coefficient (b) values for the Ames location (Tables 5 and 6). At the Mead and West Lafayette locations, there was a significant direct-distance effect for big bluestem and for indiangrass at Mead, although the $R^{2}$ values were small. The $b$ value was positive for big bluestem at the Mead location, indicating that the further the collection site distance was from the Mead location, the greater the plant biomass production was expected to be at Mead (Table 5). For indiangrass at Mead, the regression coefficient was negative, indicating that the further the collection site was from Mead, the lower the predicted plant biomass. At West Lafayette, the direct-distance effect was negative for the big bluestem accessions, which was opposite of the results for Mead.

\section{DISCUSSION}

Big bluestem and indiangrass germplasm accessions collected from different remnant prairies differed significantly in biomass production per plant, which is a measure of plant fitness. The rankings of the accessions of both species for plant biomass were consistent at the three evaluation locations, which were in the western, central, and eastern part of the tallgrass prairie ecoregion in the 1990 Plant Hardiness Zone 5 . The limited strain $\times$ location interaction effects for big bluestem and the nonsignificance of these effects for indiangrass indicated a general lack of specific adaptation for these grasses in the US Midwest.

Regression results that quantify the effect of the northto-south distance on plant biomass are in agreement with earlier similar reports on big bluestems from the western part of the tallgrass prairie and the Great Plains (Law and Anderson, 1940, McMillan, 1959; Newell, 1968). This north-south effect also occurs with switchgrass (Casler et al., 2004, 2007) and is due to photoperiod effects. In switchgrass, winter survival affects the limit of the distance that southern germplasm can be moved north. There was not a winter survival problem with the accessions evaluated at the three locations. Significant north-to-south regressions demonstrated that moving southern germplasm of big bluestem north resulted in increases in plant biomass

Table 6. Regression statistics for the regression of mean plant biomass (g plant ${ }^{-1}$ ) of indiangrass germplasm accessions from remnant prairies at three Midwestern evaluation sites on the distance $(\mathrm{km})$ and directional distance between the evaluation site and the remnant prairie locations. The coefficients of determination $\left(R^{2}\right)$ quantify the amount of variation in biomass yield due to the distance and direction effect of the collection site from the evaluation site; the regression coefficients $(b)$ quantify the expected rate of change in plant biomass production with increasing distance of the collection site from the evaluation site. The positive or negative amount of change is dependent on the directional distance of the collection site from the evaluation site. North-south and east-west distance is the distance $(\mathrm{km})$ north $(+)$, south $(-)$, east $(+)$, or west $(-)$ of the collection site from the evaluation site; direct vector is the positive (+) distance between evaluation and collection site.

\begin{tabular}{|c|c|c|c|c|}
\hline Distance type & Statistic & Mead, NE† & Ames, IA & West Lafayette, IN \\
\hline \multirow[t]{2}{*}{ North-south } & $R^{2}$ & 0.13 & 0.07 & $0.52^{* \star}$ \\
\hline & $b\left(\mathrm{~g} \mathrm{~km}^{-1}\right)$ & -0.35 & -0.33 & $-0.44^{\star \star}$ \\
\hline \multirow[t]{2}{*}{ East-west } & $R^{2}$ & $0.26^{\star}$ & 0.13 & 0.08 \\
\hline & $b\left(\mathrm{~g} \mathrm{~km}^{-1}\right)$ & $-0.42^{*}$ & -0.38 & 0.15 \\
\hline \multirow[t]{2}{*}{ Direct vector } & $R^{2}$ & $0.22^{*}$ & 0.01 & 0.10 \\
\hline & $b\left(\mathrm{~g} \mathrm{~km}^{-1}\right)$ & $-0.43^{*}$ & -0.18 & -0.17 \\
\hline
\end{tabular}

${ }^{\star},{ }^{* *}$ Significant at the 0.05 and 0.01 probability levels, respectively.

$\dagger n=20$ for each site. 
at the three evaluation locations. Although the evaluation sites were in a narrower latitudinal range than the collection sites, the same general north-to-south results would be expected at other latitudes in the Midwest region, except that there would possibly be more winter damage at more northern latitudes if germplasm was moved too far north. Based on the predicted responses and the lack of winter injury for both grasses at the three locations, using germplasm from a Plant Hardiness Zone immediately south of the hardiness zone in which a planting area is located would be an effective use of plant resources in an era of global climate change.

East-to-west effects for both big bluestem and indiangrass are probably precipitation related. The annual precipitation in eastern Nebraska is $>150 \mathrm{~mm}$ less than the precipitation received in central Iowa and farther east (US Climate Data, 2017). As a result of these differences in annual precipitation, the big bluestem accessions from the eastern prairies may have more genetic biomass production potential on average than those from the western prairies but with relatively low predictability. For indiangrass, the western prairie accessions may have the potential for greater periodic drought tolerance, which would account for the negative east-to-west regression effect for indiangrasses evaluated at Mead.

Direct-distance regressions produced nonsignificant or confusing results compared with the north-to-south or east-to-west regressions. The regressions indicate that direct-distance measurements between a collection site and an evaluation or proposed planting site are poor estimators of potential fitness as measured by biomass production per plant.

Big bluestem accessions with the greatest plant biomass came from prairies in Illinois, Missouri, and Iowa, demonstrating the considerable geographic distances between the collection sites. As an example, IL60 was collected in eastern Illinois, whereas MO60 and MO1 were collected in eastern and western Missouri, respectively (Table 3, Fig. 1). The three indiangrass accessions with the greatest average plant biomass were collected from prairies in Nebraska, Kansas, and western Missouri (Table 4, Fig. 2), whereas other high-yielding accessions were from Illinois. These examples clearly show that the accessions with the greatest biomass production per plant, which is a measure of fitness, are well adapted to the entire evaluation region.

Results of this study do not support the local adaptation concept but demonstrate that the big bluestem and indiangrass accessions from the tall grass prairie are broadly adapted in their ecoregion and Plant Hardiness Zone and that latitude and longitudinal effects are more important than the proximity of a collection site to an evaluation location as a predictor of biomass yield or fitness. These results are very similar to those reported by Casler et al. (2007) for switchgrass. Reports in the ecological literature that have been used in support of the local adaptation concept for these grasses (Mendola et al., 2014, Johnson et al., 2015) are actually comparisons of germplasms of these grasses from different ecoregions in contrasting evaluation ecoregions that, in some instances, were widely separated in distance. Analyses of big bluestem populations using molecular marker technologies indicate that populations from distinctly different ecoregions do differ genetically to some degree, and that these differences are more associated with ecoregions than geographical distances among populations (Price et al., 2012; Gray et al., 2014). The word "local," which basically means in the vicinity or neighborhood, is simply being misused when comparisons are being made between plants from different ecoregions spatially separated by hundreds of kilometers.

The local adaptation concept is based on the belief that the plants at a prairie site are there because of the results of natural selection, and hence they are the best plants for that specific site. As pointed out in his final book, evolutionary biologist Stephen J. Gould (2002) stated that natural selection is not an optimizing force and that plants only have to be good enough to maintain their place in a site. The local adaptation concept also fails to take into consideration that other evolutionary processes including mutation, migration, and random drift are also involved, and they all have random components. Random drift can have important effects on migrating populations of plants and, along with mutation, can be a primary determinant of genetic diversity (Clegg, 1997). Inbreeding depression can occur in localized populations, which can reduce fitness (Ellstrand and Elam, 1993). As a result of random drift, mutation, and inbreeding, some local populations may have unique genetic characteristics that restoration ecologists rank as highly desirable (Knapp and Rice, 1996). However, even unique genetic characteristics do not make a population of plants the most fit for a site, especially in an era of global climate change. As a result of the same random processes, some prairie sites can end up having a superior gene pool for an array of traits that make them highly fit as measured by biomass productivity over a broad ecoregions. Examples would be the superior accessions identified in this report.

Plants from the superior accessions are being used in the USDA-ARS grass breeding project at Lincoln, NE. The first experimental strains developed from these accessions have been evaluated in regional trials. Based on the preliminary results from those trials, one or more cultivars may be released for use in the Midwestern United States. The use of the best prairie accessions, such as the ones identified in this study, in the development of improved big bluestem and indiangrass cultivars for use in pastures and biomass production fields will be needed in the future because of global climate change. In 2012, a new USDA Plant Hardiness Map was released (Daly et al., 2012). This 
map clearly shows that plant hardiness zones have moved approximately one-half of a hardiness zone north in the prairie regions of the United States (Daly et al., 2012). As an example, in the 1990 Hardiness Zone Map, the northern half of Nebraska was in Hardiness Zone 4. In the 2012 map, the entire state is now in Hardiness Zone 5.

The global climate change that is occurring is causing a geographical redistribution of plants and animals, which will result in new ecological communities (Pecl et al., 2017). As global warming progresses, the plants in native prairies will be less and less adapted to their environment. With the exception of places such as the Flint Hills of Kansas and the Nebraska Sandhills, tall grass prairie remnant sites are geographically isolated, and hence also genetically isolated. Plant populations of these prairies may not have the genetic potential to respond to the large expected climatic changes. It is beyond the scope of this paper to address all potential solutions to this problem. However, it would be prudent to use plants from the best populations to develop composite populations for restoration purposes to meet the challenges of global climate change. The results of this study strongly suggest that southern germplasm should be preferred for any type of revegetation, and that the use of "local ecotypes" in an era of rapid global climate change is very questionable.

\section{Conflict of Interest}

The authors declare that there is no conflict of interest.

\section{References}

Alderson, J., and W.C. Sharp. 1994. Grass varieties in the United States. Agric. Handb. 170. Soil Conserv. Serv., USDA, Washington, DC. doi:10.5962/bhl.title.97052

Bailey, R.G. 1995. Description of the ecoregions of the United States. 2nd ed. revised and expanded (1st ed. 1980). Misc. Publ. no. 1391 (revised). US Forest Serv., Washington, DC.

Boe, A., K.H. Keeler, G.A. Normann, and S.L. Hatch. 2004. The indigenous bluestems of the western hemisphere and gambagrass. In: L.E. Moser, L. Sollenberger, and B. Burson, editors, Warm-season $\left(\mathrm{C}_{4}\right)$ grasses. Monogr. 45. ASA, CSSA, SSSA, Madison, WI. p. 873-908. doi:10.2134/agronmonogr45.c26

Byers, D.L. 1998. Effect of cross proximity on progeny fitness in a rare and a common species of Eupatorium (Asteraceae). Am. J. Bot. 85:644-653. doi:10.2307/2446533

Casler, M.D., K.P. Vogel, C.M. Taliaferro, and R.E. Wynia. 2004. Latitudinal adaptation of switchgrass populations. Crop Sci. 44:293-303. doi:10.2135/cropsci2004.2930

Casler, M.D., K.P. Vogel, C.M. Taliaferro, N.J. Ehlke, J.D. Berdahl, E.C. Brummer, et al. 2007. Latitudinal and longitudinal adaptation of switchgrass populations. Crop Sci. 47:22492260. doi:10.2135/cropsci2006.12.0780

Cathey, H.M. 1990. USDA Plant Hardiness Zone Map. USDA Misc. Publ. no. 1475. U. S. Gov. Print. Office, Washington, DC.

Clegg, M.T. 1997. Plant genetic diversity and the struggle to measure selection. J. Hered. 88:1-7. doi:10.1093/oxfordjournals. jhered.a023048
Daly, C., M.P. Widrlechner, M.D. Halblieb, J. I. Smith, and W.P. Gibson. 2012. Development of a new USDA Plant Hardiness Zone Map for the United States. J. Appl. Meteorol. Climatol. 51:242-264. doi:10.1175/2010JAMC2536.1

Ellstrand, N.C., and D.R. Elam. 1993. Population genetic consequences of small population size: Implications for plant conservation. Annu. Rev. Ecol. Syst. 24:217-242. doi:10.1146/ annurev.es.24.110193.001245

Gould, S.J. 2002. An evolutionary perspective on native plants In: I have landed: The end of a beginning in natural history. Harmony Books, New York, NY. p. 335-346. doi:10.4159/ harvard.9780674063419

Gray, M.M., P. St. Amand, N.M. Bello, M.B. Galliart, M. Knapp, K.A. Garre, et al. 2014. Ecotypes of an ecologically dominant prairie grass (Andropogon gerardii) exhibit genetic divergence across the U.S. Midwest grasslands' environmental gradient. Mol. Ecol. 23:6011-6028. doi:10.1111/mec.12993

Gustafson, D.J., D.J. Gibson, and D.L. Nickrent. 2004. Competitive relationships of Andropogon gerardii (big bluestem) from remnant and restored native populations and select native cultivars. Funct. Ecol. 18:451-457. doi:10.1111/j.0269-8463.2004.00850.x

Hopkins, A.A., K.P. Vogel, K.J. Moore, K.D. Johnson, and I.T. Carlson. 1995. Genetic variability and genotype $\times$ environment interactions among switchgrass accessions from the Midwestern USA. Crop Sci. 35:565-571. doi:10.2135/cropsci 1995.0011183X003500020047x

Johnson, L.C., J.T. Olsen, H. Tetreault, A. DeLaCrus, J. Bryant, T.J. Morgan, et al. 2015. Intraspecific variation of a dominant grass and local adaptation in reciprocal garden communities along a US Great Plains' precipitation gradient: Implications for grassland restoration with climate change. Evol. Appl. 8:705-723. doi:10.1111/eva.12281

Knapp, E.E., and K.J. Rice. 1996. Genetic structure and gene flow in Elymus glaucus (blue wildrye): Implications for native grassland restoration. Restor. Ecol. 4:1-10. doi:10.1111/j.1526100X.1996.tb00101.x

Law, A.G., and K.L. Anderson. 1940. The effect of selection and inbreeding on the growth of big bluestem (Andropogon furcatus, Muhl.). J. Am. Soc. Agron. 32:931-943. doi:10.2134/agronj19 40.00021962003200120003x

McLaughlin, S.B., and L.A. Kszos. 2005. Development of switchgrass (Panicum virgatum) as a bioenergy feedstock in the United States. Biomass and Bioenergy 28:515-535.

McMillan, C. 1959. The role of ecotypic differentiation in the distribution of the central grassland of North America. Ecol. Monogr. 29:285-308. doi:10.2307/1942132

Mendola, M.L., S.G. Baer, L.C. Johnson, and B.C. Maricle. 2014. The role of ecotypic variation and the environment on biomass and nitrogen in a dominant prairie grass. Ecology 96:2433-2445. doi:10.1890/14-1492.1

Mitchell, R.B., and K.P. Vogel. 2004. Indiangrass. In: L.E. Moser, L. Sollenberger, and B. Burson, editors, Warm-season $\left(\mathrm{C}_{4}\right)$ grasses. Monogr. 45. ASA, CSSA, SSSA, Madison, WI. p. 937-953. doi:10.2134/agronmonogr45.c28

Moore, K.J., L.E. Moser, K.P. Vogel, S.S. Waller, B.E. Johnson, and J.F. Pedersen. 1991. Describing and quantifying growth stages of perennial forage grasses. Agron. J. 83:1073-1077. doi:10.2134/agronj1991.00021962008300060027x

Moser, L.E., and K.P. Vogel. 1995. Switchgrass, big bluestem, and indiangrass. In: R.F. Barnes, D.A. Miller, and C.J. Nelson, editors, Forages. 5th ed. Vol. I: An introduction to grassland agriculture. Iowa State Univ. Press, Ames. p. 409-420. 
Montalvo, A.M., and N.C. Ellstrand. 2001. Nonlocal transplantation and outbreeding depression in the subshrub Lotus scoparius (Fabaceae). Am. J. Bot. 88:258-269. doi:10.2307/2657017

Neter, J., W. Wasserman, and M.H. Kutner, editor. 1985. Applied linear statistical models. 2nd ed. Richard D. Irwin, Homewood, IL.

Newell, L.C. 1968. Effects of source and management practice on forage yields of two warm-season prairie grasses. Crop Sci. 8:205210. doi:10.2135/cropsci1968.0011183X000800020022x

Pecl,G.T., M.B. Araújo, J.D. Bell, J. Blachard, T.C. Bonebrake, I.-C. Chen, et al. 2017. Biodiversity redistribution under climate change: Impacts on ecosystems and human well-being. Science 355:eaai9214. doi:10.1126/science.aai9214

Price, D.L., P.R. Salon, and M.D. Casler. 2012. Big bluestem gene pools in the central and northeastern United States. Crop Sci. 52:189-200. doi:10.2135/cropsci2011.05.0280

Risser, P.G., E.C. Birney, H.D. Blocker, S.W. May, W.J. Parton, and J.A. Wiens. 1981. The true prairie ecosystem. U. S./Int. Biol. Progr. Synthesis Ser. 16. Huchinson Ross Publishing Co., Stroundsburg, PA.

SAS Institute. 1999. The SAS online doc. Version 8. SAS Inst., Cary, NC.

Satterthwaite, F.E. 1946. An approximate distribution of estimates of variance components. Biometrics 2:110-114. doi:10.2307/3002019
US Climate Data. 2017. US Climate Data. Version 2.3. https:// www.usclimatedata.com/ (accessed 26 Dec. 2017).

Vogel, K.P. 2000. Improving warm-season forage grasses using selection, breeding, and biotechnology. In: K.I. Moore and B.E. Anderson, editors, Native warm-season grasses: Research trends and issues. CSSA Spec. Publ. 30. CSSA and ASA, Madison, WI. p. 83-106.

Vogel, K.P., M.D. Casler, and B.S. Dien. 2017. Switchgrass biomass composition traits and their effects on its digestion by ruminants and bioconversion to ethanol. Crop Sci. 57:275281. doi:10.2135/cropsci2016.07.0625

Vogel, K.P., S. Gautam, A.J. Saathoff, and R.B. Mitchell. 2011. Switchgrass. In: N.G. Halford and A. Karp, editors, Energy crops. The Royal Soc. Chem., Cambridge, UK. p. 341380.

Vogel, K.P., A.A. Hopkins, K.J. Moore, K.D. Johnson, and I.T. Carlson. 2006a. Genetic variation among Canada wildrye accessions from Midwest remnant prairies for biomass yield and other traits. Crop Sci. 46:2348-2353. doi:10.2135/cropsci2006.01.0020

Vogel, K.P., M.R. Schmer, and R.B. Mitchell. 2005. Plant adaptation regions: Ecological and climatic classification of plant materials. Rangeland Ecol. Manage. 58:315-319. doi:10.2111/1551-5028(2005)58[315:PAREAC]2.0.CO;2 